\title{
Discussion on Enterprise Development Approach under the Background of International Trade Friction
}

\author{
Yingxu Li \\ Hanshan Normal University, Chaozhou, 521041, China
}

Key words: International trade, Friction, Enterprises, Development approach

\begin{abstract}
Under the new world economic situation, the number of international trade friction faced by the Chinese enterprises is increasing continuously, with industries involved increasingly wide and frequent technical trade friction, which has seriously influenced the development of foreign trade of Chinese enterprises. The market competition caused by the systematic factor and trade structure, deep political and economic reasons and other reasons comprehensively intensify the trade friction. We should reduce the trade friction and improve the enterprises' ability to deal with friction through joint efforts of government and enterprises, comprehensive enterprise competitiveness, acceleration of industrial upgrading, strengthening of industrial partnership and early warning, so as to promote the Chinese enterprises to carry out international trade continuously and stably.
\end{abstract}

\section{Introduction}

The frequent occurring of trade friction has made China become the largest victim of global anti-dumping and guarantee measures, and this has also become an important factor to influence the development of international trade and adjustment of industrial structure of China. Therefore, it has become extremely practically significant to sustain the status of China as a large trade country and achieve the transformation development of domestic economy by deeply analyzing the status of international trade friction of the Chinese enterprises and the its reasons, so as to explore an effective method to solve the international trade friction.

\section{Main performances of international trade friction suffered from by the Chinese enterprises}

China is the world second largest economic entity and the world first largest export country. In 2014, under the condition that the domestic economy slowed down, China had a total export up to USD 2.34275 trillion, increasing by $6.1 \%$ on a year-on-year basis, with import and export increasing rate $2.7 \%$ higher than the global trade increasing speed. As a large trade country, China has suffered from increasingly frequent export trade friction cases, which have new performances.

\section{Number of trade frictions increases continuously}

Statistics have shown that China has become a country suffering the most anti-dumping investigation for 19 consecutive years and the most anti-subsidy investigation for 9 consecutive years. According to the statistical method of WTO, from 2002 to 2014, countries in the world launched 783 anti-dumping investigations to China. In recent years, the number of trade remedy cases in China has increased rapidly, in 2007 before breakout of the crisis, totally 18 countries launched 76 trade remedy investigations to China, and until 2012, totally 21 countries had launched 77 trade remedy investigations to China, and this number increased to 89 in 2013 and to 97 in 2014. The cases in 2014 included 61 anti-dumping investigations, 14 anti-subsidy investigations, 22 guarantee measures, and totally 22 countries and regions launched trade remedy investigation up to USD 10.49 billion. In addition, the products of China also suffered from 12 investigations launched by America and 1 anti-avoiding investigation and anti-absorption investigation respectively launched by EU, and the number of trade friction cases has increased significantly. 


\section{Industrial scope influenced by trade friction is expanding}

First, the products in the traditional middle and low-end manufacturing industry are still the hot spots of friction. The products in the middle and low-end manufacturing industry involve in the cases from hardware, mineral products, electromechanical products, from light industry, textile to iron \&steel and household appliance, with quite a wide range. Such products in China have advantages in quality and price, can rapidly enter the foreign market and have a large shares, with quite fierce competition in the market competition of the enterprises of import countries, so they have become the key concern of anti-dumping of the western countries.

Second, the high-tech products have become new hot spots of friction. With the transformation of manufacturing in China to "smart manufacturing" in China, the international competitiveness of high-tech products in China is also increasing continuously, with trade continuously increasing, becoming a new hot spot of friction.

\section{Technical trade frictions are more diversified and strongly elusive}

More countries establish technical standard, demonstration mechanism, health quarantine and other systems by issuing laws, regulations and provisions, so as to increase the requirements for the imported countries technologically, and the diversified technical trade barrier has become the most hidden and difficult-to-treat non-tariff barrier in the international trade. Actually, the developed countries have quite tight intellectual property right system, and have formed a complete strategic system in WTO and other international organizations and in restricting the developing countries. Therefore, under the condition of imperfect legal system, insufficient social concern and lack of awareness, many enterprises are investigated by the western enterprises in intellectual property right in the process of trade operation. The diversified and exclusive technical trade barriers have seriously restricted the export of Chinese products.

\section{Main reasons for international trade friction of the Chinese enterprises}

\section{Trade friction caused by systematic reasons}

The disputes caused by various countries in the international trade-related field in terms of system and policy difference are called systematic trade frictions. With the deepening of global economic integration, the industrial policy and trade policy of a country have also crossed the country, which have influences on the product competitiveness of other countries, and on the other hand, affect the establishment and implementation of industrial policies and systems of other countries, so as to influence the playing of policy of that country, and a lot of systematic frictions have thus been generated. First, when the industrial and trade policies of a country damage the corresponding industry of that country, that country will adjust its policy to deal with the damage, or apply pressure by means to make the other side adjust industrial or trade policies. For example, in 2011, China was forced to suspend two policies on supporting proprietary innovation in government support due to the pressure from other countries. Second, compared with the rapidly developed international trade system, there is still a large difference in the trade policy and system in China, and it does not act on the international convention very well. Therefore, in terms of promotion of fair trade, improving policy transparency, strengthening market entry, unveiling investment policy, promotion of intellectual property right protection, establishment of exchange rate policy and industrial policy, China will often suffer from the system restriction and duties of WTO and other international organizations, thus causing the discrimination of other countries to China, and this has become one of the reasons for other countries to launch trade friction to China.

\section{Market competition caused by trade structure factors}

The structure of products exported by China have been transformed from the primary products to manufactured industrial products, but the labor-intensive products with low technical content and single structure still account for a large proportion, the exported products of such industry are supplementary to the industrial structure of the western countries, but they have suffered from the 
strong resistance from tariff and quota, anti-dumping, anti-subsidy and other trade measures due to low-price output. After the crisis, the developed countries have adjusted the industrial policy, with manufacturing industry returned to homeland, and the competition of manufacturing industry is further intensified, and the trade frictions aimed at the manufacturing products of China are more frequent. Besides, the emerging countries and a lot of developing countries have similarity with China in terms of product technology and trade structure, with fierce competition in striving for international market and local market. Take China and ASEAN as an example, the two have relatively strong homoplasy in overall trade structure and have become mutual competitors in the low value-added comparative advantageous products like textile and clothing and high value-added comparative inferior products like machines and precise instruments. The friction degree is also closely associated with the industrial relation between two countries. However, the deeper reason behind the phenomenon that trade structure and enterprise market competition cause trade friction is the motivation that various countries protect and maintain their own interests.

\section{Deep political and economic reasons under the complicated situation}

First, low-carbon economy is the new political and economic reason for the trade friction. Low-carbon economy is the main battlefield of international political and economic game in the future, which is a strategic issue integrating politics, economy and technology. The essence of carbon tariff policy of Europe and America is the new green technical barrier for the purpose of weakening the competitiveness of products exported by developed countries with the covering of environmental protection. Meanwhile, by virtue of their strong R\&D abilities, they occupy the leading status and market of new energy, energy saving, environmental protection and other emerging technologies, and the fundamental purpose is to maintain their economic development and force other countries to accept the low-carbon economic system and system rules established by them, and realize the leading right in the future international economic stage. Second, the world political and economic patterns are changing. The western developed countries have their economy greatly stricken with low recovery, and their international political and economic statuses are weakened; relatively, the status of emerging countries and developing countries represented by China is increasing, so political intention and trend aimed at the trade remedy of China are increasingly continuous. This can be reflected from the fact that the that the overall decreasing of American anti-dumping investigation globally, but the number of anti-dumping investigation to China is rising perpendicularly, and that America seeks for regional economic cooperation but launches "reasonable" trade protectionism to China.

\section{Approach selection of Chinese enterprises in development when facing international trade friction}

\section{Deal with trade friction through defense and attach balance and joint efforts of government and enterprises}

Once in case of trade friction, enterprises should work together with government to take active responding strategy and make efforts for coordination to avoid the further aggression of the other side, and reduce the demonstration effect formed to the third countries due to unbeneficial response-stir up dispute and benefit from the international trade friction with China. For example, in the process of anti-subsidy investigation, as the respondent of anti-subsidy investigation is government, so the government is required to prove the strongest evidence within the shortest time to justify its decision. At the same time, during the response, be sure to act on the international convention in concept, get used to the fact that the western countries refer to the discrimination and dispute to, work together with the government for full cooperation, discuss and negotiate in the form of government, industrial and enterprise cooperation, guarantee the active status in response and resist firmly, so as to avoid the limiting measures of other countries and maintain the national and own interest. Meanwhile, it is required to be good at applying the trade rules of WTO and other international organizations with double-edged sword nature. While performing the obligations, it is also required to use rule to 
maintain own legal rights and interests, and actively participate in the establishment of trade rules and minimize the occurring of trade friction.

\section{Change concept and comprehensively improve the comprehensive enterprise competitiveness}

Comprehensively improving the enterprise competitiveness is an effective approach to sustain the continuous development of enterprises and reduce the trade friction. Therefore, enterprises should pay attention to the product quality management, position the quality value of exported product in international horizon, build quality awareness, strictly control quality, establish regulated and normalized quality evaluation system and improve the quality competitiveness. Second, under the background that the international competition is developed from product competition to brand competition, enterprises are urgent to build brand awareness, and on the basis of improving product quality, actively cultivate and establish proprietary brand, internationalized marketing, participate in the brand competition of international market and improve the product brand competitiveness. Finally, under the condition that intellectual property right has become a serious friction area, enterprises should be fully aware the proposition that technical innovation is both the root for enterprise survival and development, and also the key to reduce the trade friction. Therefore, enterprises should change the original development approach, obtain fund, introduce and cultivate new technology through government support, industrial joint and financial funding, actively research and develop, enhance proprietary innovation ability, improve the scientific and technological content of products, transform the low-quality and low-price competition strategy into the strategy of relying on the core product competitiveness and enhance the defense ability and pressure resistance ability to deal with trade friction.

\section{Upgrade industry, improve enterprise internationalization}

For a long time, limited by the factor endowment and technical condition, China has paid too much attention to scale and speed while ignoring quality and efficiency in the process of economic development and foreign trade, the exported products have low investment, and high energy consumption and pollution, but very low quality and economic efficiency. China has long been in the low end of international industrial chain in the international labor division. Therefore, it is required to change the current situation of relying on the low-cost advantage to participate in the international labor division, see the disadvantages of extensive economic development model and continuously promote the transformation from element driving to innovative driving, so as to establish a real modern industrial system that can deal with the international competition. Especially it is required to make great efforts to develop high-tech industry, seize the commanding height of the future international industrial competition with low-carbon concept new energy, energy-saving and environmental protection industry, biological technology and information technology, and research and develop toward both ends of the value chain and step toward the market with the most favorable smiling curve value. Meanwhile, it is required to accelerate the industrial agglomeration and integration, form industrial longitudinal labor division chain centered on the core product, play the agglomeration effect, improve overall industrial competitiveness and comprehensively improve the enterprise internationalization, so as to increase the ability to deal with the trade friction.

\section{Internally combine, play the leading role of industrial association}

The enterprise industrial association should actively provide the information in terms of export, so as to strengthen the guidance and supervision to the industry, promote the enterprises to strengthen self-discipline and form a more perfect discussion and negotiation mechanism. On this basis, it is also possible to consider to establish a special fund or financing platform to deal with the international trade friction through the industrial association, and the fund can be paid according to the sales amount of the association members, yield or income, so that the enterprises can obtain a certain lawsuit winning fund while encountering trade friction. On the basis of improving the enterprise competitiveness, it is possible to play the synergistic effect, encourage enterprises to centrally research and develop and continuously launch new technologies and products, urge the government 
to strengthen protection of intellectual property right, assist the government to fully support the export capacity of high-tech product enterprises with proprietary intellectual property right and high-tech products, support the development of enterprise internationalization internally and become the strong support for the enterprises to deal with trade friction.

\section{Strengthen early warning, reduce the loss caused by trade friction}

It is required to devote to establishing an early warning system after occurring of international trade friction, so as to improve the subjective initiatives of the Chinese enterprises to effectively deal with many trade frictions. In the level of system, it is required to form and strengthen the safety warning system and forecast system of exported products. It is possible to strengthen the trade remedy database system of innovative export products, traditional exported commodities and sensitive commodities, actively form a more effective and dynamic foreign trade industrial protection mechanism. It is required to pay attention to the long-term tracking of specific export trade, especially the export price of some products and abnormal fluctuation of quantity in sensitive markets, and timely use the early warning system and efficient prevention means to practically reduce the incidence of friction. Meanwhile, relevant departments should strengthen the mutual communication and contact, make great efforts to guide and coordinate the Chinese enterprises to participate in the response, actively cultivate high-quality talents that can properly deal with the foreign trade dispute, apply the foreign trade warning system as far as possible to reduce the loss caused by friction loss and guarantee the industrial development and economic safety of China.

\section{References}

[1] Liu Yongping, Discussion on Governance Strategy of Normalization of Trade Friction, International Trade, 2014 (12).

[2] Wan Shouyi, Chi Zheng Why do the Chinese Export Enterprises Suffer from Anti-dumping Investigation? Research on Financial and Economic Problems, 2014 (11).

[3] Yin Xiangshuo, Li Chunding, Type, Reason, Effect and Dissolution Approach of International Trade Friction, World Economy, 2007 (7)

[4] Li Jianping, Zhang Naili, Research on Influence of Trade Friction on Enterprises' Entry into International Market Model, Lingnan Journal, 2014 (1)

[5] Change of Chinese Foreign Trade Pattern and Prevention of Trade Friction under the Strategy of “One Belt and One Road”, China Business and Market, 2015 (5) 